CONCERNING THE TWO CHIEF WORLD SYSTEMS 







\section{GALILEO GALILEI}

Dialogue Concerning

the Two Chief World

Systems-Ptolemaic \&

Copernican translated

by Stillman Drake, fore-

word by Albert Einstein

SECOND EDITION

UNIVERSITY OF CALIFORNIA PRESS

Berkeley, Los Angeles, London 
Second Revised Edition, 1967

Standard BOOK Number 520-00450-7

Library of Congress Catalog Card Number 53-11 238

67890

\begin{abstract}
Alteration of the fore matter and notes to reflect substantial changes of viewpoint by the translator has been refused publication herein by the Editorial Committee of the University of California Press.
\end{abstract}

UNIVERSITY OF CALIFORNIA PRESS, BERKELEY AND LOS ANGELES, CALIFORNIA

UNIVERSITY OF CALIFORNIA PRESS, LTD., LONDON, ENGLAND

Copyright, 1953, 1962, and 1967, by tue Regents of the University of California PRINTED IN THE UNITED STATES OF AMERICA DESIGNED BY JOHN B. GOETZ 
Take note, theologians, that in your desire to make matters of faith out of propositions relating to the fixity of sun and earth you run the risk of eventually having to condemn as heretics those who would declare the earth to stand still and the sun to change position - eventually, I say, at such a time as it might be physically or logically proved that the earth moves and the sun stands still.

-Note added by Galileo in the preliminary leaves of his own copy of the Dialogue. 